\title{
IODP Expedition 301 Installs Three Borehole Crustal Observatories, Prepares for Three-Dimensional, Cross-Hole Experiments in the Northeastern Pacific Ocean
}

\author{
by Andrew T. Fisher, Tetsuro Urabe, Adam Klaus \\ and the IODP Expedition 301 Scientists
}

\section{Introduction and Goals}

The basaltic upper oceanic crust comprises the largest aquifer on Earth, containing a volume of water about equal to that currently stored in ice sheets and glaciers. Annual fluid fluxes through the upper oceanic crust are at least as large as the global river flux to the ocean. Much of the seafloor is hydrogeologically active, but the majority of the fluid flow within oceanic crust occurs on ridge flanks, regions located kilometers or more from active seafloor spreading centers. Fluid circulation in these areas is driven mainly by lithospheric heat rising from deep within the plate but is influenced by seafloor and basement topography, seismic and tectonic events, and tides.

Subseafloor fluid flow on ridge flanks influences a diverse array of processes and properties, including the thermal state and evolution of oceanic plates, alteration of the lithosphere and crustal pore waters, establishment and maintenance of vast subseafloor microbial ecosystems, and diagenetic, seismic, and magmatic activity along plateboundary faults. Although numerous drilling expeditions and surface and submersible surveys over the last several decades have focused on hydrogeologic phenomena, we still know relatively little about driving forces, property distributions, scales of flow, rates of flow, extent of compartmentalization or isolation of distinct fluid-rock systems, or links between hydrogeologic, geochemical, microbiological, and geophysical processes. Progress through drilling has been limited in the past by the perturbing effects of borehole creation on subseafloor thermal, pressure, chemical, and biological conditions. Subseafloor observatories address this challenge by allowing the formation to recover from drilling perturbations, and also allow scientists to run passive and active experiments for years to decades.

IODP Expedition 301 was part of a multi-disciplinary program designed to evaluate the formation-scale hydrogeologic properties within oceanic crust, determine how fluid pathways are distributed within an active hydrothermal system, and elucidate relations between fluid circulation, alteration, microbiology, and seismic properties. The complete experimental program will comprise two IODP expeditions (the first having been Expedition 301, the second to be scheduled), an offset seismic experiment, and long-term monitoring and cross-hole tests facilitated with submersible and remotely operated vehicle (ROV) expedi- tions extending 6-10 years after the first IODP expedition. The experimental program will also take advantage of opportunities related to a plate-scale network of long-term observatories (NEPTUNE) currently being planned.

\section{Experimental Setting and Earlier Work}

The Endeavour segment of the Juan de Fuca Ridge (JFR) generates lithosphere west of North America. Topographic relief produces barriers to turbidites from the continental margin, resulting in the accumulation of sediment over the eastern flank of the JFR, particularly during Pleistocene sea-level low stands. This resulted in burial of oceanic basement rocks under thick sediments at a young age. Sediment cover is sparse and oceanic basement is exposed near the active ridge at the western end of this ridge flank (Fig. 1). The sediment layer becomes thicker and more continuous to the east, with basement exposed at only a few, isolated outcrops. Basement relief is dominated by linear ridges and troughs oriented subparallel to the spreading center and produced mainly by faulting, variations in magmatic supply at the ridge, and off-axis volcanism. Basement relief is low $( \pm 100-200 \mathrm{~m})$ near the active ridge and higher $( \pm 300-700 \mathrm{~m})$ to the east. Low-permeability sediment limits advective heat loss across most of the ridge flank, resulting in strong thermal, chemical, and alteration gradients in the basement.

An $80-\mathrm{km}$ transect comprising ten sites was drilled on the eastern flank of the JFR during ODP Leg 168 (Davis et al., 1997), including sites aged 0.9-3.6 Ma (Fig. 1). Thermal observations at the western end of the Leg 168 transect showed that basement was cooled by seawater recharging from nearby basement outcrops. Upper basement temperatures were remarkably isothermal at the eastern end of the drilling transect, despite extreme basement relief below thick sediments, giving evidence for vigorous convection in the oceanic crust. Upper basement temperatures generally increase from $\sim 15^{\circ} \mathrm{C}$ at the western end of the transect to $\sim 64$ ${ }^{\circ} \mathrm{C}$ at the eastern end. This overall trend in basement temperatures might suggest that the dominant direction of fluid flow is from west to east, but sedimentary and basement pore fluid samples are inconsistent with this interpretation. The western end of the transect shows increasing alteration from west to east, but fluid recovered from sites in the middle of the transect was anomalously altered (Elderfield et al., 1999). The chemistry of these fluids is most consistent with that of fluids recovered from eastern Sites 1026 and 
1027 and from springs on nearby Baby Bare outcrop (Wheat and Mottl, 2000). Fluid ${ }^{14} \mathrm{C}$ analyses revealed some of the youngest crustal fluids at Site 1026 (Elderfield et al., 1999), but it is not possible for waters recharging the basement aquifer near the western end of the Leg 168 transect to become younger as they travel to the east and become increasingly altered. There is geochemical evidence for along-strike (south-to-north) fluid transport in basement (Wheat et al., 2000), and thermal data and hydrogeologic calculations show that recharge of Baby Bare outcrop springs (and of basement fluid recovered from Site 1026) most likely occurs through a larger basement outcrop 50 $\mathrm{km}$ to the south (Fisher et al., 2003).

Borehole hydrogeologic experiments completed in several Leg 168 basement holes indicated near-borehole formation permeabilities of $10^{-14}$ to $10^{-10} \mathrm{~m}^{2}$, with the highest permeabilities determined for the youngest sites (Becker and Davis, 2003; Becker and Fisher, 2000). These data are broadly consistent with the rest of the global data set and suggest two additional trends: a decrease in uppermost basement permeability with increasing age and variations in permeability estimated using methods with different measurement scales. Circulation Obviation Retrofit Kit (CORK) observatories were installed during Leg 168 at western Sites 1024 and 1025 and eastern Sites 1026 and 1027 to monitor borehole fluid pressure and temperature and to collect long-term fluid samples within uppermost basement. Borehole fluid responses to tidal loading and regional tectonic events indicate effective basement permeability as great as $10^{-9} \mathrm{~m}^{2}$, similar to values inferred from numerical and analytical calculations (e.g., Davis and Becker, 2004; Spinelli and Fisher, 2004).

Hole 1026B also yielded direct observations of ridgeflank fluid microbiology. Samples collected during drilling suggested the presence of microbes, and seafloor experiments assessed microbial biomass and diversity in fluids venting from the CORK observatory (Cowen et al., 2003). Cells collected from the wellhead included bacteria and archaea, whose closest known phylogenetic neighbors comprise nitrate reducers, thermophilic sulfate reducers, and thermophilic fermentative heterotrophs, consistent with basement fluid geochemistry. These tantalizing results encourage additional study of the basement biosphere.

\section{Drilling, Sampling, Testing, and Installing Borehole Observatories}

IODP Site U1301 was positioned $1 \mathrm{~km}$ south-southwest of ODP Site 1026, above a buried basement ridge where sediment thins to $250-265 \mathrm{~m}$ (Fig. 1). We cored upper basement in Hole U1301B to $\sim 580 \mathrm{mbsf}(\sim 320 \mathrm{~m}$ sub-basement, msb), with $\sim 30 \%$ recovery, typical for basaltic crust. Samples were collected to study lithostratigraphy,

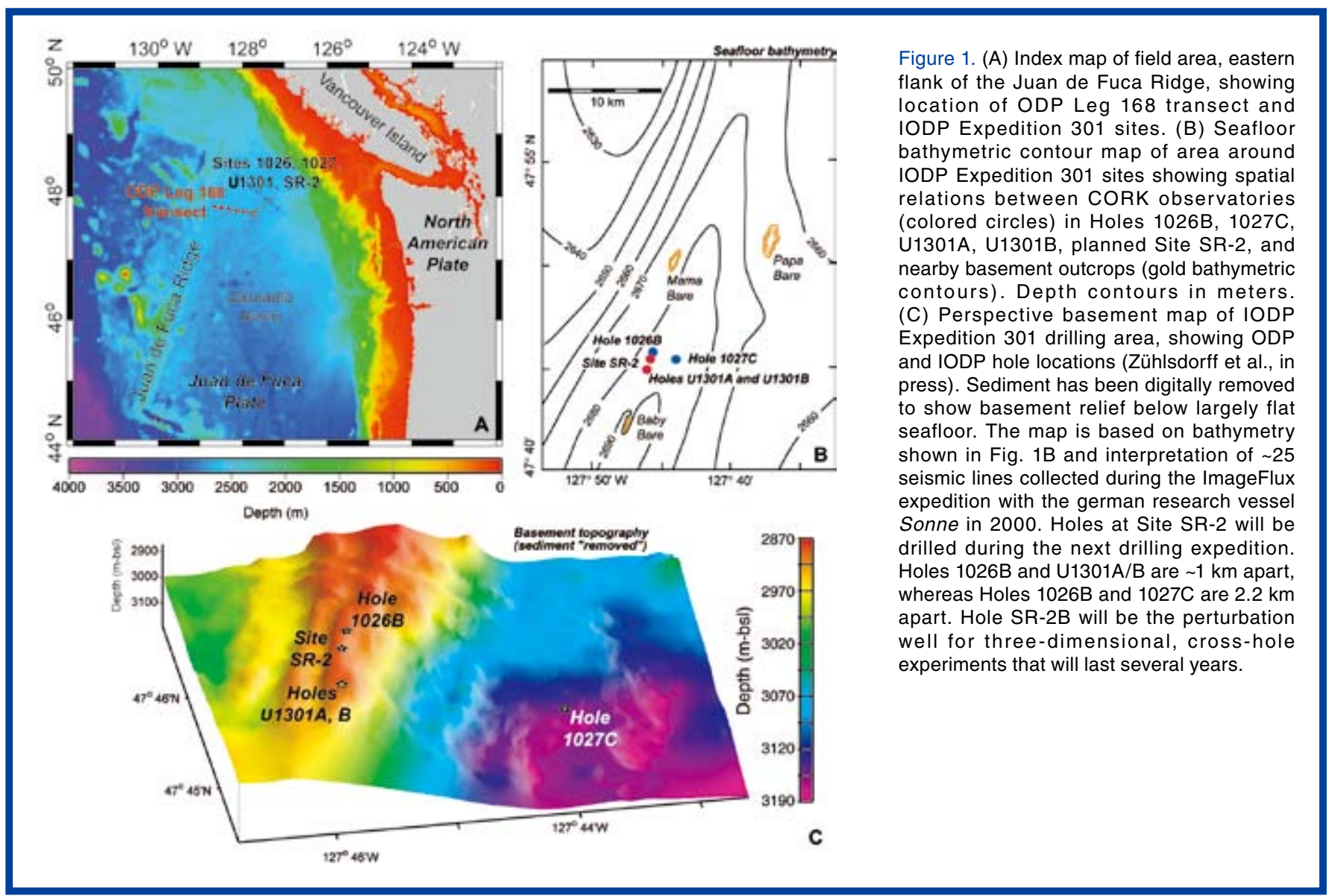


alteration, microbiology, and paleomagnetic and physical properties. Nearly $9 \%$ of recovered basement rocks were dedicated to microbiological analyses. We also collected high-quality advanced piston corer (APC) sediment cores immediately above basement to sample fluid chemistry and microbiology. Wireline logging data from the lower part of Hole U1301B indicate that the hole is to gauge and that the crust is highly layered. Comparison with other crustal holes shows that we achieved a critical basement observatory objective: isolating upper and lower parts of extrusive crust. Packer experiments completed in Holes U1301A and U1301B show that the upper crust is highly permeable, perhaps $>10^{-10} \mathrm{~m}^{2}$, and bulk permeability may decrease slightly with depth (Fisher et al., in press $a$ ).

We replaced the CORK observatory in Hole 1026B; \, created new basement Holes U1301A and U1301B that penetrate 108 and $320 \mathrm{msb}$, respectively, and instrumented each of these holes with CORK observatories (Figs. 1 and 2). CORK handling and installation is illustrated in Figure 3. Site U1301 basement holes and observatories are separated by just $35 \mathrm{~m}$. All new CORK observatories have multiple isolated intervals to monitor and sample pressure, temperature, chemistry, and microbiology and will serve as observation points for cross-hole experiments (Fig. 2). Holes 1026B and U1301A each include one monitored zone in uppermost basement, and there are three basement zones being monitored in Hole U1301B. The uppermost basement zones in these holes are in rubbly, brecciated rock, whereas the deepest crustal zone in Hole U1301B appears to be considerably more massive and stable, although it is also highly permeable. These CORK observatories include plumbing that allows us to monitor intervals between the two inner casing strings (Fig. 2A) and assess the quality of hydrologic seals. We also planned to replace the CORK system in Hole 1027C during IODP Expedition 301 but ran out of time and supplies. The old CORK system is currently monitoring basement fluid pressure within one interval and will be replaced with a more sophisticated system during the next drilling expedition (Fisher et al., in press $b$ ).

The Expedition 301 CORKs were deployed inside concentric $20 ", 16 "$ ", and 10-3/4" casing strings and use a $4-1 / 2$ " inner casing that includes one or more inflatable packers to seal monitoring intervals (Fig. 2). Pressuremeasurement systems were installed at the wellhead post-drilling by ROV (described below), using tubing to monitor depths of interest. Each Expedition 301 pressure logger monitors multiple intervals and has significantly greater memory, lower power consumption, faster communication and data download rates, less temperature sensitivity, and greater pressure resolution than previous generation tools. Hydraulic connections are provided by light-weight, submersible-mateable connectors, and the sensor and logger housings are smaller and more portable than earlier tools, making servicing by submersible or ROV easier.
The CORK fluid-sampling program makes use of pumps placed (1) at depth below the CORK seals and (2) at the seafloor on the CORK head. The first systems allow fluid to be collected within boreholes at in situ temperature, pressure, and chemical conditions, but require removal of the plugs and other instrumentation inside $4-1 / 2^{\prime \prime}$ casing to recover the samples. The second systems use valves and small-bore tubing to draw fluids from depth, making it easier for samplers to be recovered and redeployed using a submersible or ROV. The heart of each of these sampling systems is one or more OsmoSamplers. OsmoSamplers sample fluid for a specified time using osmotic pressure across a semipermeable membrane (created by solutions of differing salinity) to draw sample continuously through small-bore tubing. These systems have operated successfully during deployments of weeks to years in many settings, including estuaries, seamounts, seafloor spreading centers, and deep ocean boreholes. Four different kinds of OsmoSampler units were deployed during Expedition 301: gas sampling, microbiological, tracer injection, and acid addition. Subseafloor systems will run for five years, while seafloor systems will run for up to two years before replacement.

Microbiological colonization instruments deployed at depth within CORK observatories during Expedition 301 are intended to enable better characterization of the rates of microbial alteration of minerals and the roles of mineralogy in controlling microbial alteration. These experiments comprised two kinds of systems: (1) passive experiments in which fluids are allowed to pass over polished sections of various rock or mineral samples located inside a perforated high-density polyethylene (HDPE) sleeve between OsmoSamplers and (2) flow cells in which fluids are pumped across rock samples using OsmoSamplers. The Hole U1301B CORK also includes a clean Tefzel ${ }^{\circledR}$ microbiological sampling line extending from the wellhead to the deepest monitored basement interval.

Autonomous temperature sensors and data loggers were deployed within all three Expedition 301 CORK observatories to assist with interpreting osmotic pumping rates and to determine the thermal state, particularly the extent of thermal homogeneity, of upper basement. Autonomous loggers provide greater flexibility in deployment depths than do preconfigured, instrumented cables, are stable and robust during multi-year deployments, and make field configuration (cutting, splicing) of instrument support cables faster and easier. Temperature logging systems constructed for Expedition 301 were modified versions of commercial products, with upgraded batteries, pressure cases, and other components, and are about the size of a marking pen. These instruments provide temperature resolution and absolute accuracy of $1-30 \mathrm{mK}$ over a wide temperature range and will collect hourly data for up to five years. 


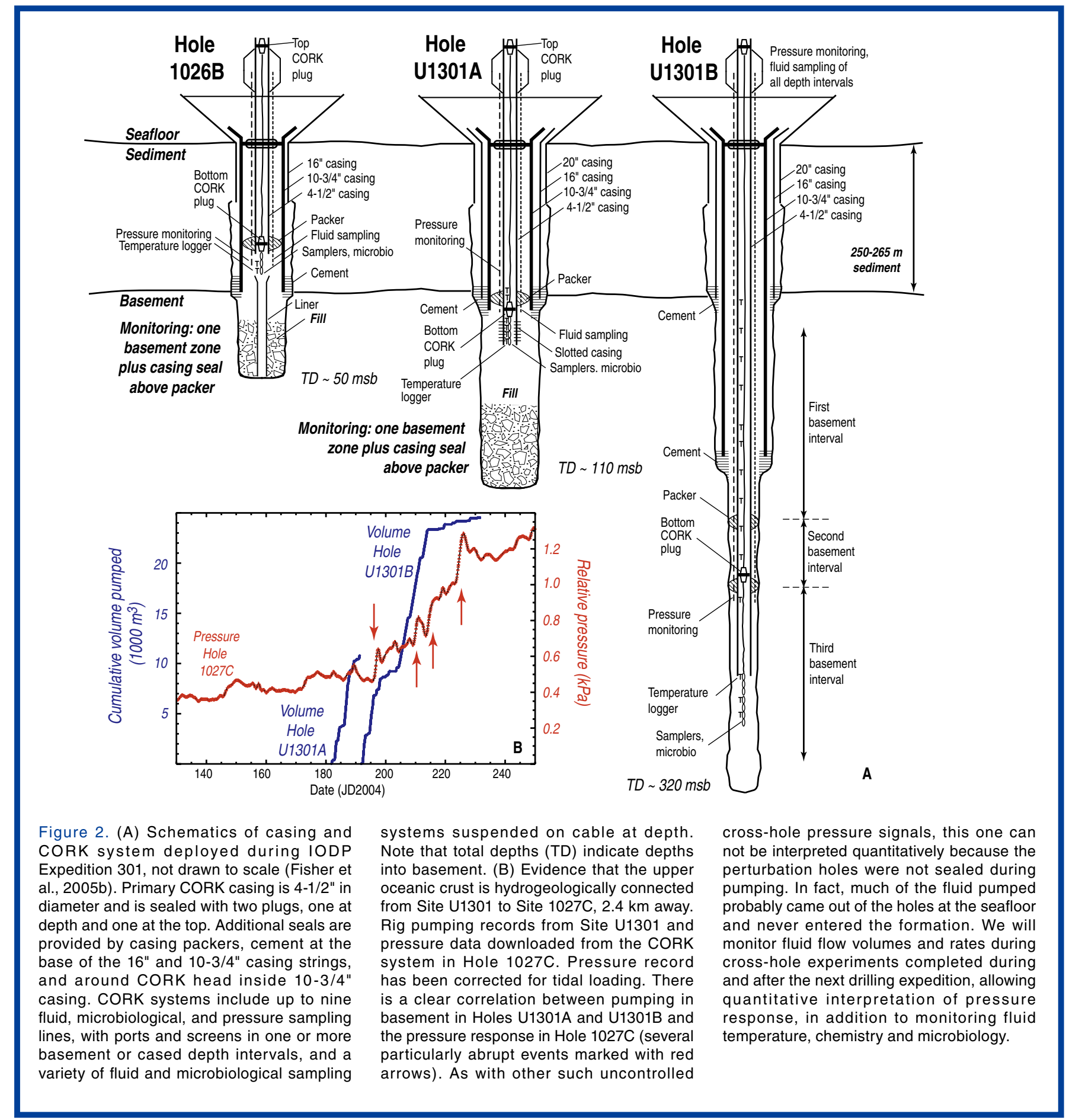

\section{Post-Expedition 301 CORK Servicing}

Expedition 301 CORKs were serviced three weeks after the drilling expedition, using the ROV ROPOS in September 2004 . The primary goals of these operations were to (1) inspect and evaluate CORK installations, (2) install pressure loggers, (3) close unused pressure and sampling valves left open for deployment (to purge air from the lines), (4) recover short-term OsmoSampling systems, and (5) install dust covers on the CORK heads to prevent clogging. Additional submersible and ROV work will occur during mid of 2005 and 2007.
All three CORKs installed during IODP Expedition 301 appear to be operating properly, but we will have more information after a planned mid 2005 Alvin program, when we can examine longer borehole pressure records. The top plugs in the CORKs at Holes 1026B and U1301A were found to be located outside of the CORK heads, whereas the top plug in Hole U1301B was found to be in place as intended. No shimmering water was seen exiting through or around the CORK heads of the Expedition 301 installations; shimmering water had been seen exiting the Hole 1026B CORK when it was leaking prior to Expedition 301. 
Data collected for a few hours with a newly installed data logger in Hole 1026B are noticeably cleaner than those collected prior to Expedition 301, probably as a result of having a better borehole seal. These data also show that the borehole fluid is overpressured relative to local hydrostatic pressure, in part as a result of the rise of warm water up the CORK casing before pressure valves were closed. Data recovered from an earlier-generation pressure logging system installed in Hole 1027C, 2400 m from Site U1301, yielded some of the most exciting results obtained during September 2004 CORK servicing. An overall increase and several abrupt changes in pressure in Hole $1027 \mathrm{C}$ correlated with pumping into Holes U1301A and U1301B, illustrating the extent of hydrogeologic connection across long distances in the crust (Fig. 2B).

\section{Plans for Future Experiments}

The next JFR drilling expedition will include initiation of multi-disciplinary, cross-hole experiments and will be followed by several years of seafloor work for observatory servicing, hydrologic perturbation, fluid, tracer, and microbiological sampling and data recovery, analytical work, and interpretation. We will replace the Hole 1027C CORK and create two new multi-level, subseafloor observatories at Site SR-2 (Figs. 1 and 2).

Hole $1027 \mathrm{C}$ is located $2.2 \mathrm{~km}$ east of Hole $1026 \mathrm{~B}$, and Site SR-2 will be located $200 \mathrm{~m}$ south of Hole 1026B (Fig. 1). The new observatories, in combination with existing systems, comprise a three-dimensional network of basement monitoring points, with borehole separation of 35 to 2500 $\mathrm{m}$, for use in cross-hole experiments. Operations in Hole $1027 \mathrm{C}$ will begin with recovering the existing CORK and deepening the hole by $30-40 \mathrm{~m}$. This will make room to hang drill collars, provide upper-crustal samples for microbiological and other analyses, and open up the formation for large-scale testing. Emplacement of a two-level CORK system will optimize the configuration for the cross-hole tests and allow acquisition of long-term geochemical and microbiological samples.

Hole SR-2A will be the deeper new basement hole, and the operational approach will be similar to that used for Hole U1301B, with drilling, casing, coring, wireline logs, vertical seismic profiling (VSP), single-hole packer work, and emplacement of a multi-level CORK. Hole SR-2B will penetrate the upper, most-permeable crustal layer(s) and will be the main perturbation well for long-term experiments. Once this hole is drilled, cased, and open sufficiently below casing, we will initiate a 24 -hour pumping test with seawater and tracers, then set a multi-level CORK observatory. Multi-year cross-hole tests will be initiated by submersible or ROV one to two years after drilling operations are complete, using the naturally overpressured formation to test properties within an enormous crustal volume.

\section{IODP Expedition 301 Scientists}

A. Fisher (Co-Chief Scientist), T. Urabe (Co-Chief Scientist), A. Klaus (Staff Scientist), A. Bartetzko, K. Becker, R. Coggon, M. Dumont, B. Engelen, S. Goto, V. Heuer, S. Hulme, M. Hutnak, F. Inagaki, G. Iturrino, S. Kiyokawa, M. Lever, S. Nakagawa, M. Nielsen, T. Noguchi, W. Sager, M. Sakaguchi, B. Steinsbu, T. Tsuji, and C.G. Wheat.

\section{References}

Becker, K., and Davis, E.E., 2003. New evidence for age variation and scale effects of permeabilities of young oceanic crust from borehole thermal and pressure measurements. Earth Planet. Sci. Lett., 201:499-508.

Becker, K., and Fisher, A.T., 2000. Permeability of upper oceanic basement on the eastern flank of the Juan de Fuca Ridge determined with drill-string packer experiments. J. Geophys. Res., 105(B1):897-912.

Cowen, J.P., Giovannoni, S.J., Kenig, F., Johnson, H.P., Butterfield, D., Rappé, M.S., Hutnak, M., and Lam, P., 2003. Fluids from aging ocean crust that support microbial life. Science, 299:120-123.

Davis, E.E., and Becker, K., 2004. Observations of temperature and pressure: constraints on ocean crustal hydrologic state, properties, and flow. In Davis, E.E., and Elderfield, H. (Eds.), Hydrogeology of the Oceanic Lithosphere: Cambridge (Cambridge Univ. Press), 225-271.

Davis, E.E., Fisher, A.T., Firth, J.V., et al., 1997. Proc. ODP, Init. Repts., 168: College Station, TX (Ocean Drilling Program).

Elderfield, H., Wheat, C.G., Mottl, M.J., Monnin, C., and Spiro, B., 1999. Fluid and geochemical transport through oceanic crust: a transect across the eastern flank of the Juan de Fuca Ridge. Earth Planet. Sci. Lett., 172:151-165.

Fisher, A.T., Davis, E.E., Hutnak, M., Spiess, V., Zühlsdorff, L., Cherkaoui, A., Christiansen, L., Edwards, K.M., Macdonald, R., Villinger, H., Mottl, M.J., Wheat, C.G., and Becker, K., 2003. Hydrothermal recharge and discharge across $50 \mathrm{~km}$ guided by seamounts on a young ridge flank. Nature (London, U.K.), 421:618-621.

Fisher, A.T., Urabe, T., Klaus, A., and the Expedition Scientists, in press a. Proc. IODP 301: College Station TX (Integrated Ocean Drilling Program Management International, Inc.).

Fisher, A.T., Wheat, C.G., Becker, K., Davis, E.E., Jannasch, H., Schroeder, D., Dixon, R., Pettigrew, T.L., Meldrum, R., McDonald, R., Nielsen, M., Fisk, M., Cowen, J., Bach, W., and Edwards, K., in press $b$. Scientific and technical design and deployment of long-term, subseafloor observatories for 


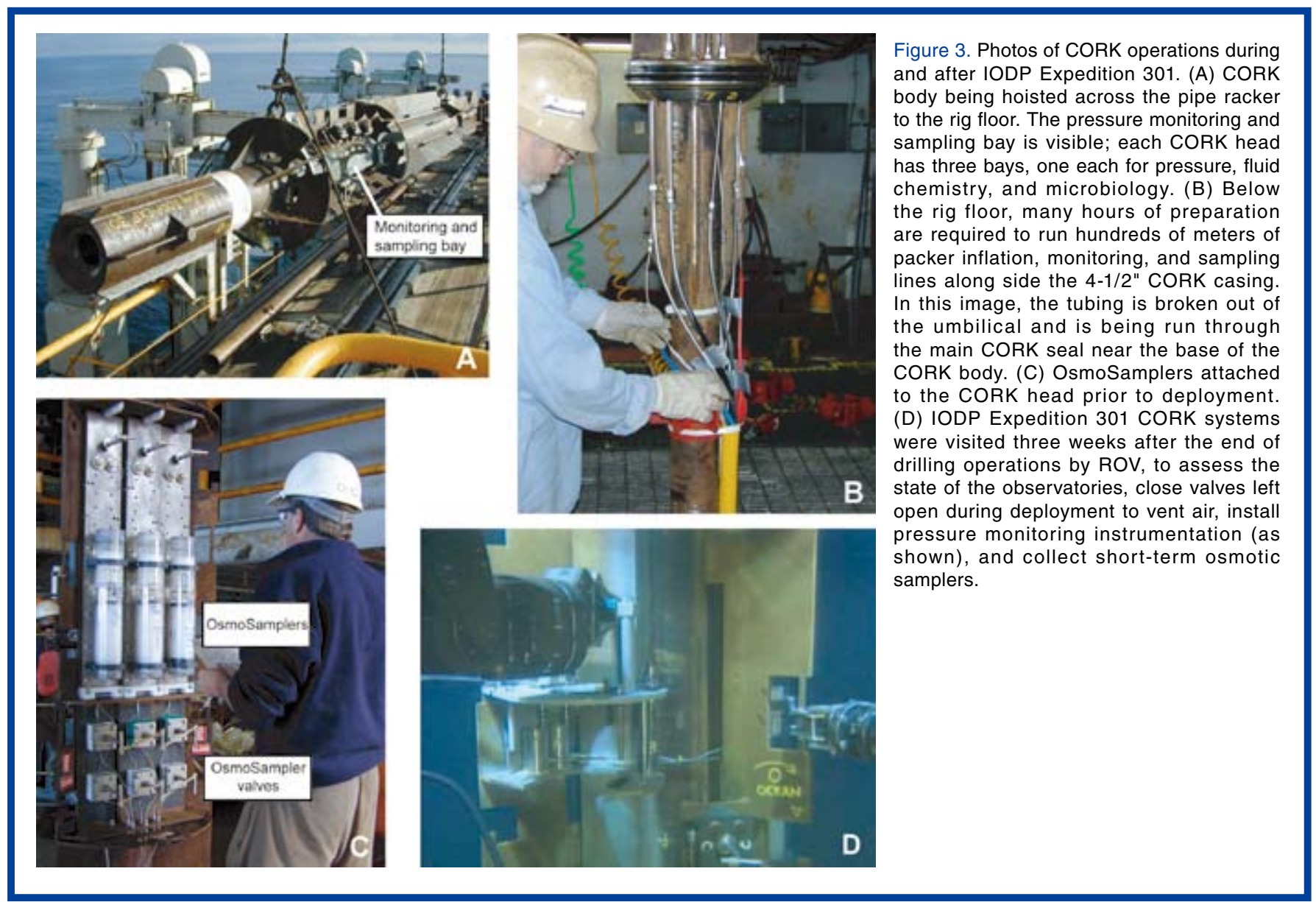

hydrogeologic and related experiments, IODP Expedition 301, Eastern Flank of Juan de Fuca Ridge. In Fisher, A.T., Urabe, T., Klaus, A., and the Expedition Scientists, Proc. IODP 301: College Station TX (Integrated Ocean Drilling Program Management International, Inc.).

Spinelli, G.A., and Fisher, A.T., 2004. Hydrothermal circulation within topographically rough basaltic basement on the Juan de Fuca Ridge flank. Geochem., Geophys., Geosyst., 5(2). doi:10.1029/2003GC000616.

Wheat, C.G., Elderfield, H., Mottl, M.J., and Monnin, C., 2000. Chemical composition of basement fluids within an oceanic ridge flank: implications for along-strike and across-strike hydrothermal circulation. J. Geophys. Res., 105(B6):13437-13448.

Wheat, C.G., and Mottl, M., 2000. Composition of pore and spring waters from Baby Bare: global implications of geochemical fluxes from a ridge flank hydrothermal system. Geochim. Cosmochim. Acta, 64(4):629-642.

Zühlsdorff, L., Hutnak, M., Fisher, A.T., Spiess, V., Davis, E.E., Nedimovic, M., Carbotte, S., Villinger, H., and Becker, K., in press. Site surveys prior to IODP Expedition 301: ImageFlux (S149) and RetroFlux (TN116) expeditions and earlier studies. In Fisher, A.T., Urabe, T., Klaus, A., and the Expedition Scientists, Proc. IODP 301: College Station TX (Integrated Ocean Drilling Program Management International, Inc.).

\section{Authors}

Andrew T. Fisher, Earth Sciences Department and Institute for Geophysics and Planetary Physics, University of California at Santa Cruz, Santa Cruz, CA 95064, U.S.A., e-mail: afisher@es.ucsc.edu

Tetsuro Urabe, Earth and Planetary Science, University of Tokyo, 7 Hongo, Bunkyo-ku, Tokyo 113-0033, Japan

Adam Klaus, Integrated Ocean Drilling Program, Texas A\&M University, 1000 Discovery Drive, College Station, TX 77845-9547, U.S.A.

and the IODP Expedition 301 Scientists

\section{Related Weblink}

http://iodp.tamu.edu/scienceops/expeditions/exp301.html 